\title{
Conodonts of the Dounans Limestone, Highland Border Complex, Scotland
}

\author{
R. L. ETHINGTON ${ }^{1} \&$ R. L. AUSTIN ${ }^{2}$ \\ ${ }^{1}$ Department of Geological Sciences, University of Missouri-Columbia, Columbia, Missouri, U.S.A. 652ll \\ ${ }^{2}$ Department of Geology, The University, Southampton, S09 5NH U.K.
}

\begin{abstract}
A meager collection of conodonts recovered from the Dounans Limestone near Aberfoyle, Perthshire, consists for the most part of species with North American affinities. This fauna reaffirms correlation of the Dounans with part of Zone J (Cassinian) of the biostratigraphic succession in western United States. The conodonts indicate that the Dounans is equivalent to part of the zone of Didymograptus nitidus (middle Arenig) in the graptolite sequence for the Ordovician.
\end{abstract}

\section{INTRODUC'TION}

The rocks of the Highland Border Complex crop out in a discontinuous narrow belt across Scotland from Arran on the southwest to Stonehaven on the northeast coast. Early efforts to describe regional stratigraphic relationships within this strongly deformed region inferred the presence of a lower interval of basic igneous rocks, black shales, and cherts that is succeeded by a younger unit comprising detrital and carbonate rocks (Barrow, 1901; Jehu and Campbell, 1917). Barrow (1901) assumed the shales and cherts to be of Arenigian age because of their lithologic similarity to fossiliferous rocks in the Southern Uplands, and he believed the carbonate-bearing unit to be indeterminately younger. Modest palaeontological evidence (summarized in Curry et al., 1984) for the temporal relations of the rocks of the Highland Border Complex was generally accepted as definitive for several decades, but eventual reconsideration of the reported fossils showed that some of them were identified erroneously and that none of them were adequate to allow precise age determination of the rocks from which they came (see e.g. Anderson, 1963).

Lack of reliable criteria for establishing the age of the Highland Border Complex caused difficulty for the reconstruction of the depositional and tectonic history of this part of Scotland. Thus, Johnson and Harris (1967) observed that the rocks of the Complex exposed along the River North Esk display structural patterns like those shown by the geographically contiguous Dalradian rocks. They interpreted this to mean that the Dalradian and Highland Border rocks were deformed simultaneously, and that the latter could be no younger than Cambrian. In contrast, Henderson and Robertson (1982, p. 441) reported that they could not correlate the cleavages shown by the Highland Border Complex and by the Dalradian in the North Esk exposures, and they suggested that these cleavages were not of synchronous origin. They interpreted the Highland Border rocks as a tectonically emplaced ophiolite complex involving oceanic crust and deep-water sediments that were deposited in a narrow, intraDalradian ocean basin. This basin was inferred to have disappeared as subduction began to close Iapetus, with the Highland Border Complex being carried southeastward as a separate thrust slice that rode along above the rocks of the Tay Nappe. According to this interpretation, a late stage of deformation rotated the Dalradian and Highland Border rocks into their present steeply dipping and nearly parallel orientation.

Still another view is expressed by Bluck (1984) who concludes that the rocks of the Highland Border Complex accumulated in a marginal basin north of a volcanic arc that occupied the region of the Midland Valley in early Palaeozoic time. He believes that the Dalradian block was a long distance away at the time because of the absence of debris of Dalradian origin in the Highland Border Complex which was deposited at a time of maximum uplift of the Dalradian. According to this interpretation, the Dalradian rocks were brought to their present position relative to the Highland Border Complex and the Midland Valley late in the time of deposition of the Old Red Sandstone. Initial emplacement is argued to have been by strike slip movement with later thrusting carrying Dalradian rocks southward over the Highland Border Complex and parts of the Midland Valley sequence. Harte and others (1984) also support the notion of strike-slip motion as the primary factor in juxtaposing the rocks now found on opposite sides of the Highland Boundary Fault. They suggest that the rocks of the Highland Border Complex were deposited in a basin that developed at a transtensional site along a strike-slip fault system, and that these rocks were transported to their present position by transform motion no later than Early Devonian time.

\section{PALAEONTOLOGY OF THE HIGHLAND BORDER COMPLEX \\ Introduction}

Fossil evidence for the age of the Highland Border Complex accumulated slowly and thereby retarded clarification of the uncertainties that have surrounded these rocks. The consensus derived from these sparse occurrences of fossils was that the Highland Border Complex was deposited primarily during the early part of the Ordovician Period. This interpretation was clouded by the discovery of Lower Cambrian trilobites (Stubblefield in Brown and others, 1965) in a thin limestone interbedded within the Leny Grits near Callendar, which created doubt about the accepted age of the rocks adjacent to the Highland Boundary Fault. In addition, Anderson (1963) presented evidence that the graptolites from a locality near Aberfoyle that had contributed significantly to the interpretation of Ordovician age cannot be identifed with confidence.

This inadequacy has been corrected during the past decade by the recovery (Curry et. al., 1984; Ingham et. al., 1985; Curry, 1986a) of fossil invertebrates at a number of localities where the Highland Border Complex is exposed. The greatest part of the collections was obtained from the Dounans Limestone in the abandoned Lime Craig Quarry overlooking Aberfoyle (see Curry. 
$1986 \mathrm{~b}$, for a detailed description of the locality). The diverse silicified fauna obtained by acid digestion of the limestone includes trilobites, brachiopods, gastropods, bryozoans, an orthoconic nautiloid, ostracodes, and pelmatozoan columnals; Arenigian age is indicated. The most definitive of the faunal elements are the trilobites which Ingham and others (1985) observed to have strong affinities with forms from the primarily North American Bathyurid Province of Whittington and Hughes (1972). Comparisons can be made with species from Spitzbergen and western Newfoundland and especially with trilobites from the Great Basin in western United States. The brachiopods, while less well-preserved and thereby less definitive, also show North American affinities (Curry and Williams, in Curry et. al., 1984).

Cadocian chitinozoa have been found in the Margie Limestone in the gorge of the River North Esk (Burton \& Curry in Curry et. al., 1984), and these fossils also are present in the Clunie Limestone near Blairgowrie (Arenig-Llandovery age) and in rocks near Aberfoyle (Bofrishlie Burn; Llanvirn-Llandeilo). The fossils recovered to date confirm that the Highland Border Complex includes rocks at least as old as Arenigian as was indicated in earlier, less well-documented biostratigraphic studies. They also demonstrate that younger Ordovician and possibly Silurian strata are present as well. Whether older rocks are included depends upon the ultimate tectono-stratigraphic interpretation of the Leny Limestone.

\section{Conodonts}

The Lime Craig Quarry was visited in the summer of 1987 to collect material from the Dounans Limestone for processing in acetic acid in an effort to recover conodonts. As reported by Curry (1986b), exposures of the limestone no longer are available owing to deep excavation while the quarry was active and to later filling of the pit by slumped conglomerate from the cliff of Old Red Sandstone that caps its southern headwall. The fine-grained grey limestone of the Dounans was found as scattered fragments that were left from the quarrying operation; 15.26 kilograms of this material was taken for processing.

The limestone was crushed to gravel-sized fragments and digested in a dilute solution of acetic acid following standard procedures for recovery of conodonts (see Stone, 1987). The limestone reacted slowly with the acid, and repeated treatment with fresh solution was necessary to carry the reaction to completion. Only 183 grams of the original sample did not pass through the coarse screen. The insoluble residues were wetscreened through a fine-mesh sieve (75 micrometer opening) which retained 487 grams of siliceous shards, dark granular masses, and fragments of silicified invertebrates. The dark granular material was removed magnetically, and the remainder of the residue was concentrated further with bromoform. The few specimens of conodonts extracted from the heavy fraction of the residues indicated Early Ordovician age but included no taxa that would permit establishment of a more precise age for the rocks

Dr. J. Keith Ingham of the Hunterian Museum, University of Glasgow, kindly provided us with 1.814 kilograms of residues obtained during the digestion of Dounans material in the earlier study that produced megafossils as recorded in Inghamet. al. (1985). Visual examination of the residue as well as dry-screening indicated that the same range of particle sizes was present as was developed in our studies of material from the Lime Craig Quarry.
Assuming that the techniques used by Dr. Ingham and ourselves were comparable so that the amount of residue per kilogram of original rock is approximately the same for the two sets of samples, the 1.814 kilograms of residue were produced by the processing of about 55.9 kilograms of rock. These residues were concentrated using the same procedures as before, and a modest number of conodonts was obtained from them including biostratigraphically signficant forms as discussed below. A single chitinozoan test, probably representing a species of Conochitina Eisenack, also was found in the residues.

The conodonts recovered from the two sets of residues comprise 48 elements representing 10 species recovered from a calculated 71 kilograms of rock. As is demonstrated by the illustrations herein, preservation is rather poor. Most of the specimens show incipient and healed fractures. Their surfaces typically are corroded, and many of them have material of the matrix adhering to them. All of the specimens are opaque and black indicating a colour alteration index (CAI) of 5.0 on the scale proposed by Epstein and others (1977). This demonstrates exposure to palaeotemperatures in the range of $300-400^{\circ} \mathrm{C}$. These temperatures may have been achieved as a consequence of the intrusion of a dolerite dyke whose outcrop extends across the mouth of the quarry.

The conodonts recovered from the two sets of residues are as follows:

Drepanoistodus sp. - erect element - I specimen

Eucharodus parallelus (Branson and Mehl) - 3 specimens

Jumudontus gananda Cooper - 6 specimens

Oistodus aff. $O$. lanceolatus Pander -8 specimens

Parapanderodus cornuformis (Sergeeva)

cornuform element -6 specimens

scandodontiform element -1 specimens

Parapanderodus striatus (Graves and Ellison) - 14 specimens

Periodon flabellum (Lindström)

Sb element - 1 specimen

Pa element - 1 specimen

Protopanderodus gradatus Serpagli - 1 specimen

Scandodus brevibasis (Sergeeva) sensu Löfgren oistodontiform element --1 specimen

distacodontiform element - 1 specimen

drepanodontiform element -3 specimens

Geniculate element, species indeterminate - I specimen

\section{Discussion}

Although sparse in number and rather poorly preserved, the conodont elements enumerated above offer further evidence for the interpretation of the Dounans Limestone. The collections include representatives of both the cold-water population of the North Atlantic Province (Sweet and Bergström, 1974) and the warm-water Midcontinent Province. Because so few specimens were recovered, dominance of the fauna is not established for either of these two components. Mixed collections are known from deep basinal deposits (e.g. Mazarn Shale in Arkansas; see Repetski and Ethington, 1977) and from shallow-platform carbonate rocks (e.g. Galena Group of Iowa and Minnesota; sec Ethington, 1959, and Webers, 1966), so that no conclusions as to the bathymetry of the basin in which the Dounans was deposited can be made using our conodont collection. The meager fauna is consistent with an outer shelf environment as postulated by 
Ingham and others (1985) in their evaluation of trilobites and other fossils from the Dounans.

The species with the most distinctly North American affinities is E. parallelus (Branson and Mehl). This species is almost ubiquitous in the Lower Ordovician shallow-water carbonates that blanket the North American craton, and it also occurs in Korea, China, Siberia, and Australia. Its stratigraphic range encompasses most of the Ibexian (= Canadian) Series in North America, so that it is present in rocks equivalent to the upper Tremadocian through much of the Arenig. Parapanderodus striatus (Graves and Ellison) also is known almost exclusively from North American occurrences, although apparently identical forms have been recorded from Arenig-Llanvirn rocks in Sweden (Löfgren, 1978). This species has a very long range in the Great Basin of western United States where it makes its appearance in rocks of late Tremadocian age (Zone E of Ross and Hintze) and continues upward into high Llanvirnian strata (Zone O).

Protopanderodus gradatus was reported initially from the Arenigian San Juan Limestone in Argentina (Serpagli, 1974) and subsequently has been shown to range in western United States from near the top of the Fillmore Formation (upper part of Zone $\mathrm{H})$ to the lower part of the Lehman Formation (lower part of Zone $\mathrm{N}$; see Ethington and Clark, 1982, for details). Landing (1976) found this species in the Deepkill Shale in beds that straddle the boundary between the zones of Tetragraptus fruticosus and Didymograptus protobifidus. The stratigraphic range of this species in North America is in beds equivalent to middle Arenig through Llanvirn. It has not been reported from Europe, although Protopanderodus rectus (Lindström), which occurs in coeval strata in northern Europe (Löfgren, 1978), is very similar morphologically; the two may be conspecific.

The species here identified as Parapanderodus cornuformis (Sergeeva) represents forms that have had various generic assignments. The symmetrical element was described by Sergeeva (1963) as a species of Scolopodus Pander. The asymmetrical element reported here has been reported by authors (Viira, 1974; Gedik, 1977) as a form-species of Scandodus Lindström, and the asymmetrical element of a closely related species was described by Barnes and Poplawski (1973) as a form-species of Protopanderodus (Lindström). Bergström (1979) interpreted the symmetrical and asymmetrical elements as the components in the apparatus of a species he assigned to Juanognathus Serpagli. This interpretation of the apparatus generally has been accepted subsequently, but other generic names have been used for it. Dzik (1976) and Stouge (1984) interpreted this apparatus as representing Semiacontiodus Miller, Dzik (1983) later placed it in Glyptoconus Kennedy, and Dzik and Drygant (1986) reported it under Parapanderodus Stouge. Sweet (1988) accepted the latter assignment with the considerable reservation that it is "as good a home for it as any," a sentiment with which we concur.

The symmetrical element of this apparatus is morphologically stable, whereas the asymmetrical element displays considerable variation. In $P$. asymmetricus, which is moderately abundant in late Ibexian through lower Whiterockian strata in North America, the asymmetrical element is flexed and twisted and shows marked curvature in the anterior margin in the basal region. In these forms the basal cavity is tear-drop shaped as viewed from beneath with the constricted region toward the anterior margin. In contrast, the asymmetrical element that we recovered from the Dounans shows much less anterior constriction of the basal cavity and lacks the pronounced curvature of the basal anterior margin of $P$. asymmetricus. The Dounans specimen is closer to elements that Löfgren (1978) reported in multielement Scolopodus cornuformis Sergeeva from the lower Llanvirnian Eoplacognathus? variabilis - Microzarkodina ozarkodella Zone in northern Sweden. She observes that this species is present as low as the late Volkhovian (= late Arenigian) Microzarkodina flabellum parva Zone. Bergström (1979) indicated that the most common element in his collections from the Hølonda Limestone near Trondheim, Norway, is an asymmetrical element that seems to us to be closer to the one we found in the Dounans than to the asymmetrical element of $P$. asymmetricus, the name under which he reported it. Other conodonts in the Hølonda collections occur in central Nevada in rocks that also contain graptolites that have been correlated with faunas from high in the zone of Didymograptus hirundo and in the zone of Didymograptus "bifidus" in Britain, i.e. latest Arenig and oldest Llanvirn.

Drepanoistodus is represented in the collection by a single specimen of the suberect element. Species of Drepanoistodus are identified by their geniculate elements; the suberect elements, like the other nongeniculate elements in the apparatuses, are stable morphologically and have not played a significant role in taxonomy. We compared our single specimen with similar elements in collections from western United States and with illustrations based on collections from elsewhere. Repetski (1982) illustrated a specimen whose lateral outline is very similar to the Dounans specimen in his report of Drepanoistodus suberectus subsp. A from the El Paso Group of west Texas where the range of such elements is in rocks equivalent to middle Tremadocian through lower Arenigian. Löfgren (1978) included comparable elements as part of Drepanoistodus basiovalis (Sergeeva), which she found in middle Arenigian through middle Llanvirnian strata in northern Sweden. Elements like the one illustrated here were included in Drepanoistodus forceps (Lindström) by Dzik (1976) to describe material he obtained from erratic boulders in Poland; he interpreted the age of the fauna as upper Arenigian (Paroistodus originalis Zone). Ethington \& Clark (1982) considered similar suberect elements that they found in Arenigian strata in western United States to be part of the apparatus of a species close to $D$. forceps. Finally, specimens in undescribed collections from the basal Whiterockian Orthidiella Zone at the Whiterock Canyon Narrows in central Nevada appear to be identical to the Dounans specimen. Although we cannot identify the species to which this specimen should be assigned, the foregoing comparisons indicate that it is morphologically very like the suberect elements of Arenigian to Llanvirnian species of Drepanoistodus.

Specimens representing several elements of the apparatus of Oistodus Pander were found, but they are too broken to be identified. The genus has been recognized in late Ibexian and Whiterockian (upper Arenig-Llanvirn) strata in North America, and similar ranges are known from Europe.

Three elements from the collection are very similar to specimens from the middle Arenigian Paroistodus originalis Zone in northern Sweden that Löfgren (1978) considered part of the apparatus of Scandodus brevibasis (Sergeeva). Specimens like those identified herein as drepanodontiform were described under the name Scandodus flexuosus Barnes and Poplawski by 
Ethington \& Clark (1982) and as Scandodus cf. furnishi from the San Juan Limestone of Argentina (Serpagli, 1974) and the El Paso Group in Texas (Repetski, 1982). Each of these latter occurrences is in Arenigian strata.

Jumudontus gananda was described by Cooper (1981) from the Horn Valley Siltstone of the Amadeus Basin in central Australia in which this species is associated low in its range with Oepikodus evae (Lindström) and is joined higher in the section by Baltoniodus navis (Lindström). These latter species are diagnostic of middle Arenigian (uppermost Latorpian and basal Volkhovian) conodont zones in Sweden that have been correlated with parts of the British graptolite zones of Didymograptus extensus and Didymograptus hirundo. Jumudontus gananda has been found to range rather widely in North America (see Ethington \& Clark, 1982, for summary) where it is distributed through upper Ibexian to lower Whiterockian strata (from the upper part of Zone $\mathrm{H}$ into Zone L) in the Ibex section of western Utah; other reports of it are based on relatively few specimens whose occurrences are stratigraphically consistent with this range. Bergström (1988) identified this species from the early Arenigian Zone of Prioniodus elegans at localities near Leningrad and in southecntral Sweden, respectively. The specimen that he illustrated has the distinctive posterior basal expansion that is characteristic of Jumudontus, but it differs from $J$. gananda in being foreshortened in the anterior-posterior dimension and in having only four stubby, conical denticles. The P. elegans Zone is older than the strata from which this species has been recorded previously. Because of this as well as the morphologic differences from typical $J$. gananda, we suggest that the specimens from the Baltic region represents an older species of Jumudontus.

Periodon Hadding is represented by one specimen each of the $\mathrm{Sb}$ element and the $\mathrm{Pa}$ element. Species of Periodon are distinguished most reliably by the conformation of the $M$ element which we did not find, so that our identification of these specimens with P. flabellum (Lindström) is tentative. Löfgren (1979) observed that the differences between the P and S elements of $P$. flabellum and its descendant Periodon aculeatus Hadding are "subtle and gradual." She noted that the mean number of denticles between the cusp and the major denticle on the posterior process is 4.7 or more in $\mathrm{S}$ elements of $P$. aculeatus in her collections from northern Sweden. The specimen we found in the Dounans has four denticles in this interval. Löfgren found elements showing four denticles in this position in rocks ranging from middle Volkhovian (= upper Arenig, Zone of Didymograptus hirundo) through upper Kundan ( = lower Llanvirnian, Zone of Didymograptus "bifidus"). The Pa element from the Dounans limits the top of the range for this occurrence, however, in that it has only one denticle anterior to the largest one in the series. According to Löfgren, this configuration of $P$ elements is restricted in her collections to specimens from rocks of Arenigian age (zones of $D$. extensus and $D$. hirundo).

Periodon is known best from northern Europe and is interpreted as a conodont that is typical of the cold-water North Atlantic Province. The genus has been reported from numerous places in North America, but usually on the basis of occasional specimens included in collections strongly dominated by species typical of the warm-water Midcontinent Province. Periodon is much more common and frequently is the dominant component in basinal deposits of deep water origin flanking the North American platform. In the type area of the Whiterockian Stage in central Nevada, $P$. flabellum occurs in the upper Ninemile Shale (late Ibexian) in association with Oepikodus evae (Lindström). The latter species is diagnostic of a middle Arenigian conodont zone in the widely used zonal scheme for the North Atlantic Province established by Lindström (1971). Periodon flabellum ranges above the Ninemile and into the lower part of the overlying Antelope Valley Formation (lowest Whiterockian) where it is replaced by the descendant species, $P$. aculeatus.

The remaining specimen in our collection is an $M$ element with a short base and a broad, thin posterior denticle that is broken distally. Anterior to this thin denticle is the stump of a thicker denticle that has been broken proximal to the base. Linear striae begin near the basal margin beneath the stump of this denticle and continue upward to the fractured margin; the thin posterior denticle is nonstriate. The element is broken anteriorly, and we cannot reconstruct what existed ahead of the thick denticle prior to loss of the anterior extremity. We compared this specimen with the $\mathrm{M}$ elements known to us from collections that contain the species discussed above. Closest resemblance, primarily based on the shape of the base of the element, is with the $M$ element of Bergstroemognathus extensus (Graves and Ellison), but the upper part of the Dounans specimen is sufficiently different that we cannot justify identifying it with that species.

\section{CONCLUSIONS}

Just as was reported for invertebrates in the earlier palaeontological studies of the Dounans (Ingham et. al., 1985; Curry et. al., 1985), conodonts are rare in this limestone unit. We recovered species that are considered to be typical cold/deepwater forms in about equal numbers with those believed to be characteristic of warm/shallow conditions, so that a definitive palaeoenvironmental interpretation cannot be made from these conodonts. The few available specimens are consistent with a shelf-margin condition as was postulated by Ingham et. al. (1985)

Explanation of Plate 1

Figs 1, 3. Parapanderodus striatus (Graves and Ellison); 1, lateral view, X87; 3, posterior view, X100. (HM Y348, HM Y349).

Figs 2, 9. Parapanderodus cornuformis (Sergeeva); 2, symmetrical element, X60; 9, asymmetrical element, X93. (HM Y346, HM Y347).

Fig. 4. Protopanderodus gradatus Serpagli, X207. (HM Y352).

Figs 5, 8. Scandodus brevibasis (Sergeeva) sensu Löfgren; 5, distacodontiform element, X200; oistodontiform element, X80. (HM Y354, HM Y353).

Fig. 6. Eucharodus parallelus (Branson and Mehl); X100. (HM Y343).

Fig. 7. Drepanoistodus sp.; suberect element, X113. (HM Y342)

Fig. 10. Geniculate element of uncertain affinity, X160. (HM Y355).

Figs 11, 12. Periodon flabellum (Lindström); 11, Pa element, X160; 12, Sb element, X153. (HM Y351, HM Y350).

Figs 13, 14. Jumudontus gananda Cooper; lateral views; 13, X73' 14, X87. (HM Y344, HM Y345). 


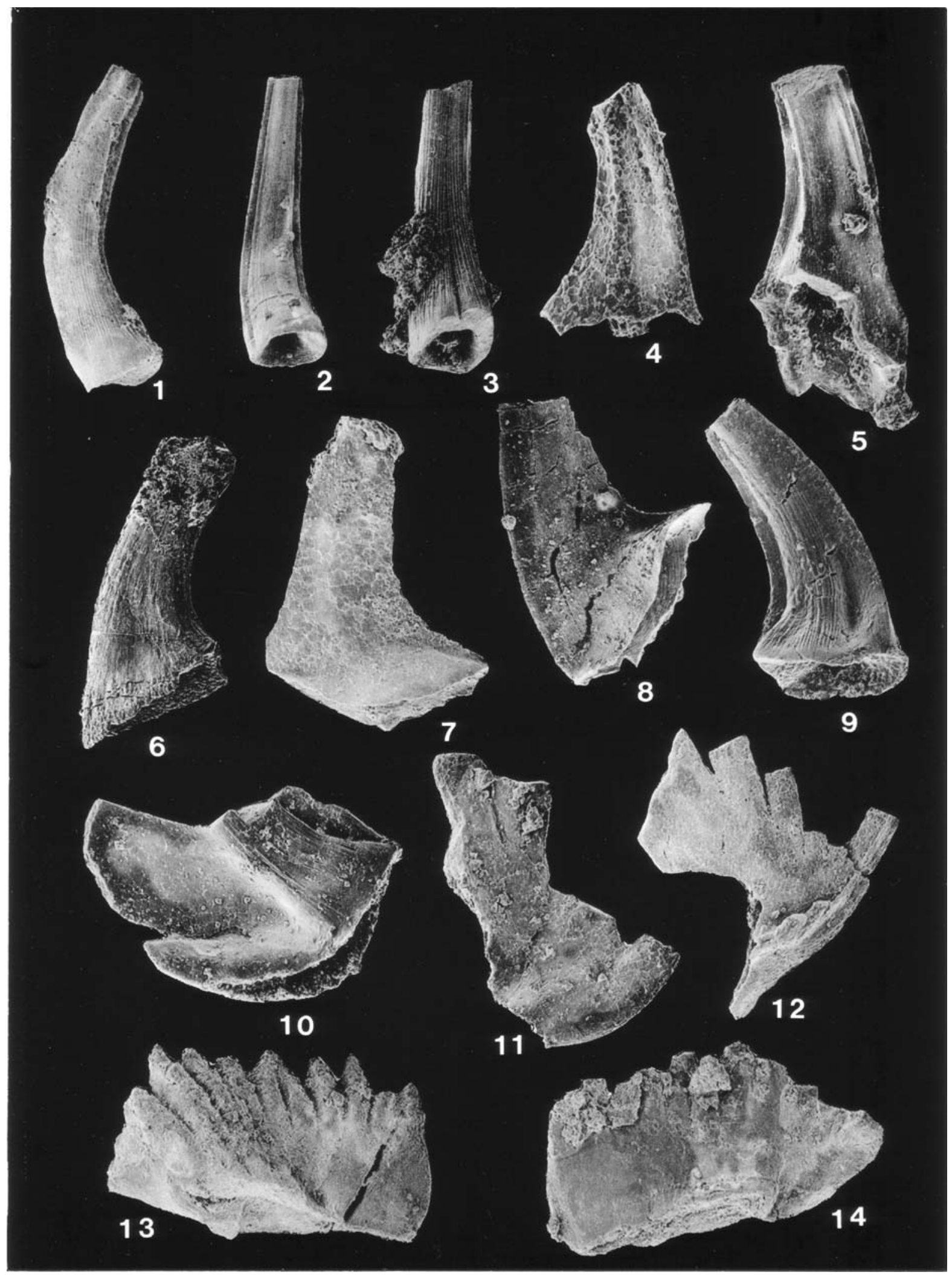


in their evaluation of Dounans trilobites. Most of the conodont species are taxa that are known primarily from North American occurrences; they reinforce the strong North American affinities for Dounans fossils already established for the invertebrates.

Some of the conodont species obtained in our investigation have long stratigraphic ranges, but most of them are restricted to late Ibexian through Whiterockian rocks in occurrences in western United States. The presence of $P$. flabellum indicates that the Dounans can be correlated within the interval of Ross/Hintze zone $\mathrm{J}$ through lower zone $\mathrm{L}$. This stratigraphic interval in western United States is considered to encompass the Cassinian Stage of North American stratigraphic terminology, and to be approximately equivalent to the British zone of Didymograptus nitidus (Ross et al., 1982). It corresponds to much of the zones of Oepikodus evae and of Baltoniodus triangularis in the conodont zonation of the cold water (North Atlantic) province. The conodonts support the correlation of the Dounans with late Ibexian Zone $J$ in North America that Ingham et al. (1985) made primarily from the trilobites of the formation, although most of them range at least as high as the lowest Whiterockian Zone L.

\section{ACKNOWLEDGEMENTS}

Study of the conodonts of the Dounans Limestone was undertaken in the course of a research leave granted to the senior author by the University of Missouri-Columbia and funded in part by a Hartley Visiting Fellowship awarded to him by the University of Southampton. He is very appreciative of the courtesies extended to him by Professor Robert Nesbitt and the faculty and staff of the the Department of Geology, University of Southampton.

Permission to collect in the Achray National Forest was given by officers in the Aberfoyle office of the Forestry Commission. We are indebted to Drs. B. J. Bluck, C. J. Burton, and G. B. Curry of the Department of Geology, University of Glasgow, for discussions about the Highland Border Complex, and to Dr. J. K. Ingham of the Hunterian Museum, University of Glasgow, for providing the acid residues from the Dounans Limestone from which a significant part of the conodonts of this study were recovered. Figured specimens are deposited in the collections of the Hunterian Museum, University of Glasgow under the catalogue numbers shown on the plate legend; the balance of the collection is deposited in the Hunterian Museum.

\section{Manuscript received May 1990}

Revised manuscript accepted December 1990

\section{REFERENCES}

Anderson, F. W. 1963. Palaeontology. Summ. Prog. Geol. Sum. Great Britain (1962).

Barnes, C. R. \& Poplawski, M. L. S. 1973. Lower and Middle Ordovician conodonts from the Mystic Formation, Quebec, Canada. Jl. Paleontol., 47, 760-790.

Barrow. G. 1901. On the occurrence of Silurian (?) rocks in Forfarshire and Kincardinshire along the eastern border of the Highlands. Q. Il. geol. Sor London, 57, 328.345.

Bergström, S. M. 1979. Whiterockian (Ordovician) conodonts from the Hølonda Limestone of the Trondheim Region, Norwegian Caledonides. Norsk geol Tidsskr., 59, 295-307. 15

Bergström, S. M. 1988. On Pander's Ordovician conodonts: distribution and significance of the Prioniodus elegans fauna in Baltoscandia. Senckenbergiana Lethaea, 69, 217-251.

Bluck, B. J. 1984. Pre-Carboniferous history of the Midland Valley of Scotland. Trans roy. Soc. Edinburgh : Earth Sci., 75, 275-295.

Brown, P. E., Miller, J. A., Soper, N. J. \& York, D. 1965. Potassium-argon age pattern of the British Caledonides. Proc. Yorks geol. Soc., 35. 103-138

Cooper, B. J. 1981. Early Ordovician conodonts from the Horn Valley Siltstone, central Australia. Palaeontology, 24, 147-183.
Curry, G. B. 1986a. Fossils and tectonics along the Highland Boundary Fault in Scotland. Jl. geol. Soc. London, 143, 193-198.

Curry, G. B. 1986b. Tailormade geology 3: Lime Craig Quarry, Aberfoyle, Scotland Geol. Today, Jan-Feb 1986, 25-27.

Curry, G. B., Bluck, B. J., Burton, C. J., Ingham, J. K., Siveter, D. J. \& Williams. Alwyn. 1984. Age, evolution and tectonic history of the Highland Border Complex, Scotland. Trans, roy, Soc. Edinburgh, 75, 113-133.

Dzik, Jerzy. 1976. Remarks on the evolution of Ordovician conodonts. Acta Palaeoniol. Polonica, 21, 395-455.

Drik, Jerzy. 1983. Relationships between Ordovician Baltic and North American Midcontinent conodont faunas. Fossils and Strata, 15, 59-85.

Dzik, Jerzy, \& Drygant, D. M. 1986. The apparatus of panderodontid conodonts. Lethaia, 19, 133-141.

Epstein, A. G., Epstein, J. B., \& Harris, L. D. 1977. Conodont color alteration-an index to organic metamorphism. U. S. geol. Surv. Prof. Paper, 995, 1-27.

Ethington, R. L. 1959. Conodonts from the Ordovician Galena Formation. $J$ Paleontol., 33, 257-292.

Ethington, R. L. \& Clark, D. L. 1982. Lower and Middle Ordovician conodonts from the Ibex area, western Miltard County, Utah. Brigham Young Univ. Geol Studies, 8(2), 1-160.

Gedik, I. 1977. Orta Toroslar'da konodont biyostratigrafisi [Conodont biostratigraphy in the Middle Taurus, in Turkish]. Turk. Jeol. Kurumu Bul.. 20. $35-48$.

Harte, B., Booth, J. E., Dempster, T. J., Fettes, D. J., Mendum, J. R., \& Watts, D 1984. Aspects of the post-depositional evolution of Dalradian and Highland Border Complex rocks in the Southern Highlands of Scotland. Trans. roy. Sor: Edinburgh, 75, 151-164.

Henderson, W. G. \& Robertson, A. H. F. 1982. The Highland Border rocks and their relation to marginal basin development in the Scottish Caledonides. $\mathrm{Jl}$. geol. Soc. London, 139, 433-450.

Ingham, J. K., Curry, G. B. \& Williams, Alwyn. 1985. Early Ordovician Dounans Limestone fauna, Highland Border Complex, Scotland. Trans. roy. Soc Edinburgh, 76, $481-513$.

Jehu, T. J. \& Campbell, R. 1917. The Highland Border rocks of the Aberfoyle District. Trans. rov. Soc. Edinburgh, 52, 175-212

Johnson, M. R. W. \& Harris, A. L. 1967. Dalradian-?Arenig relations in part of the Highland Border, Scotland, and their significance in the chronology of the Caledonian orogeny. Scott. Jl. Geol. 3, 1-16.

Landing, E. 1976. Early Ordovician (Arenigian) conodont and graptolite biostratigraphy of the Taconic Allochthon, eastern New York. Jl. Paleontol., 50 614-646.

Lindström, M. 1971. Lower Ordovician conodonts of Europe. Geol. Soc. Amer. Mem., 127, 21-61.

Löfgren, A. 1978. Arenigian and Llanvirnian conodonts from Jamtland, northern Sweden. Fossils and Strata. 13, 1-129. 17

Repetski, J. E. 1982. Conodonts from El Paso Group (Lower Ordovician) of westernmost Texas and southem New Mexico. New Mexico Bw. Mines Min. Res Mem., 40, 1-121.

Repetski, J. E. \& Ethington, R. L. 1977. Conodonts from the graptolite facies in the Ouachita Mountains, Arkansas and Oklahoma. Arkansas Geol. Comm. Srmp Geol. Ouachita Mts., 1, 92-106.

Ross, R. J. \& Others. 1982. The Ordovician System in the United Stares: Correlation Chart and Explanatory Notes. Internat. Union geol. Sci. Pub., 12, 1-73.

Sergeeva, S. P. 1963. Konodonty iz Nizhnego Ordovika Leningradskoi Oblasti [Lower Ordovician conodonts from the Leningrad region, in Russian]. Paleontol. Zh, 1963(2),92-108

Serpagli, E. 1974. Lower Ordovician conodonts from Precordilleran Argentina (Province of San Juan). Boll. So . Paleontol. Ital., 13. 17-98.

Stone. J. J. 1987. Review of investigative techniques used in the study of conodonts. In Austin, R. L. (Ed.). Conodonts: Investigative Techniques and Applicarions. Ellis Horwood Limited, Chichester, 17-34.

Stouge, S. S. 1984. Conodonts of the Middle Ordovician Table Head Formation. westem Newfoundland. Fossils and Strata. 16. 1-145.

Sweet, W. C. 1988. The Conodonta. Morphology. Tawonomy, Paleoecology and Erolutionary History of a Long-Extinct Animal Phylum. Oxford Univ. Press. Oxford Mon. Geol. Geophys., 10, 1-212.

Sweet, W. C., \& Bergstrom, S. M. 1974. Provincialism exhibited by Ordovician conodont faunas. In Ross, C. A. (Ed.). Paleogeographic Provinces and Prorinciality. Soc. Econ. Paleontol. Mineral. Spec. Pub.. 21. 189-202.

Viira, V. 1974. Konodonty Ordorika Pribaltiki IOrdovician Conodonts of the East Baltic, in Russian|. Inst. Geol. Akad. Nauk Estonsk. SSR. Tallin. 1-142.

Webers, G. F. 1966. The Middle and Upper Ordovician conodont faunas of Minnesota. Minnesora Geol. Swr. Spec. Pub.. 4. 1-123.

Whittington, H. B. \& Hughes, C. P. 1972. Orodvician geography and faunal provinces deduced from trilobite distribution. Phil. Trans. Rov So Lombon. B263. 235-278 